\title{
IDENTIFIKASI BATUAN GRANIT DAERAH PROSPEK PANAS BUMI NYELANDING MENGGUNAKAN METODE MAGNETIK
}

\author{
Ahmat Munawir Siregar ${ }^{1}$, Ira Kusuma Dewi ${ }^{2}$, Ngatijo $^{3}$ \\ Universitas Jambi ${ }^{1,2,3}$ \\ ahmatmunawirsiregar@gmail.com
}

\begin{abstract}
This study aimed to identify granite rocks around the Nyelanding geothermal area, especially in the geothermal manifestations. This research used the magnetic method to analyze the subsurface structure of the geothermal area. Correction of magnetic data was performed in Microsoft excel 2010 software and two-dimensional modeling was performed using Oasis Montaj 8.4. The results showed that there are three layers of rock under Nyelanding hot springs, namely granite with a susceptibility of 0.009-0.05 SI to a depth of 500 meters and a layer of sandstone - clay, as well as layers of clay, gravel and silt with a susceptibility of 0.00001 - 0, 00005 SI. In conclusion, the local geology of the Nyelanding hot spring area is dominated by the presence of granite to a depth of 500 meters. The results of forward modeling on layers $A-A^{\prime}$ and $C-C^{\prime}$ show the subsurface structure of Nyelanding hot springs in the form of a granite rock basin which is estimated to be able to accumulate geothermal energy.
\end{abstract}

Key words: Nonvolcanic Geothermal, Magnetic Method, Granite Susceptibility, Forward Modeling

\begin{abstract}
Abstrak: Penelitian ini bertujuan untuk mengidentifikasi batuan granit di sekitar panas bumi Nyelanding terutama di manifestasi panas bumi tersebut. Penelitian ini menggunakan metode magnetik untuk menganalisi struktur bawah permukaan daerah panas bumi. Koreksi pada data magnetik dilakukan di perangkat lunak Microsoft excel 2010 dan pemodelan dua dimensi dilakukan dengan menggunakan Oasis Montaj 8.4. Hasil penelitian menunjukkan bahwa terdapat tiga perlapisan batuan di bawah air panas Nyelanding yaitu batu granit dengan suseptibilitas 0,009 - 0,05 SI hingga kedalaman 500 meter dan lapisan batu pasir - lempung, serta lapisan lempung, kerikil dan lanau dengan suseptibilitas 0,00001 - 0,00005 SI. Simpulan, geologi lokal daerah air panas Nyelanding didominasi oleh keberadaan batu granit hingga kedalaman 500 meter. hasil forward modelling pada lapisan A-A'dan C-C' menunjukkan struktur bawah permukaan air panas Nyelanding berupa cekungan batu granit yang diperkirakan dapat mengakumulasi panas bumi.
\end{abstract}

Key words: Panas Bumi Nonvulkanik, Metode Magnetik, Suseptibilitas Granit, Forward Modelling

\section{PENDAHULUAN}

Energi panas bumi merupakan energi yang berasal dari rembesan air ke bawah permukaan yang terperangkap dalam waktu yang lama dan memiliki temperatur yang tinggi. Energi panas bumi mempunyai kaitan yang erat dengan sistem panas bumi pembentuknya (Afandi et al. 2013). Sistem panas bumi terdiri dari sistem panas bumi vulkanik, vulkano- tektonik dan non-vulkanik (Pitulima \& Siregar, 2016). Sistem panas bumi vulkanik adalah sistem panas bumi yang berasosiasi dengan gunung api kuarter yang terletak di sepanjang busur vulkanik. Adapun sistem panas bumi vulkano-tektonik merupakan sistem panas bumi yang berasosiasi antara struktur graben dan kerucut vulkanik. Selain itu, sistem panas bumi nonvulkanik merupakan sistem panas bumi yang tidak berkaitan langsung dengan vulkanisme. Lingkungan non-vulkanik di Indonesia bagian barat tersebar di bagian timur sundaland (paparan sunda) yang tersebar dari Kepulauan Riau hingga Kepulauan Bangka Belitung (Kasbani, 2013).

Sistem panas bumi di pulau Bangka termasuk kedalam system panas bumi non vulkanik (Putri \& Harianja, 2021). Sistem panas bumi non-vulkanik tersebut memiliki banyak sekali manifestasi seperti salah satunya yang berada di Desa Nyelanding (Franto, 2015). Daerah prospek panas bumi Nyelanding diperkirakan seluas $1 \mathrm{~km}^{2}$ dari penyebaran manifestasi permukaannya. Manifestasi panas bumi Nyelanding berupa 
mata air panas dengan temperatur $49^{\circ} \mathrm{C}$. Struktur geologi di sekitar panas bumi Nyelanding pada umumnya berupa sesar mendatar berarah timurlaut-barat daya serta sesar normal dan sesar mendatar berarah barat laut - tenggara. Data geokimia menunjukkan adanya anomali $\mathrm{Hg}$ tanah dan anomali $\mathrm{CO}_{2}$ udara tanah. Berdasarkan geotermometer silika sebesar $90^{\circ} \mathrm{C}$ yang termasuk dalam entalpi rendah dengan rapat daya sebesar $5 \mathrm{MWe} / \mathrm{km}^{2}$ dan luas daerah prospek sebesar $1 \mathrm{~km}^{2}$, maka didapatkan nilai potensi sebesar 5 MWe. Berdasarkan latar belakang tersebut, penelitian ini dilakukan dengan tujuan untuk mengidentifikasi batuan granit di sekitar panas bumi Nyelanding terutama di manifestasi panas bumi tersebut.

\section{TINJAUAN PUSTAKA}

\section{Geologi Daerah Penelitian}

Batuan granitik di pulau Bangka dapat digolongkan kedalam 2 tipe yaitu tipe batuan beku (Igneous type) dan tipe batuan sedimen (Sedimentary type) (Chappel \& White, 2001). Batuan Kuarter ditemukan berupa lumpur, kerakal, kerikil, lempung yang terdapat sebagai endapan sungai, rawa dan pantai berupa Aluvium (Qa). Lumpur, lanau dan pasir yang berupa Endapan Rawa (Qs) dan Pasir Kuarsa (Qak.)

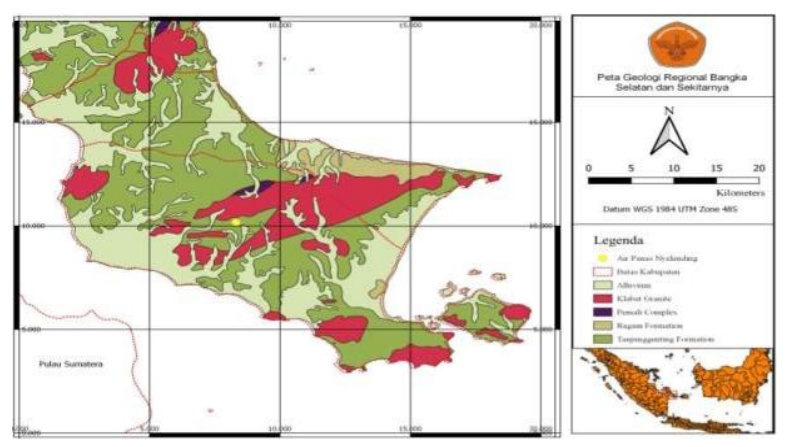

Gambar 1. Peta geologi Bangka Selatan

Daerah Bangka Selatan tersusun oleh beberapa formasi atau satuan batuan secara urut dari muda ke tua sebagai berikut, pertama aluvium (Qa) terdiri dari bongkah, kerakal, kerikil, pasir, lempung dan gambut;
Pasir Berkarbon (Qpk) berupa pasir karbonan kehitaman bersisipan lempung. Tidak padu, berbutir sedang sampai halus, mengandung mineral berat dan lignit. Setempat, dijumpai lapisan yang mengandung mineral kasiterit. Satuan ini menindih tak selaras batuan pra tersier, ketebalan sekitar 1-5 m.

Kedua, Formasi Ranggam (TQr), formasi ini terdiri atas perselingan batupasir, batulempung dan konglomerat. Batupasir berwarna putih kotor, berbutir halus- kasar, subrounded-rounded, mudah diremas, berlapis baik; struktur sedimen berupa silang silur, paralel laminasi dan graded bedding; setempat ditemukan lensa-lensa batubara dengan tebal 0,5 meter dan mengandung pasir timah sekunder yang tercampur dengan batupasir kuarsa. Batulempung mengandung sisa-sisa tumbuhan dan lensa gambut. Konglomerat berfragmen pecahan granit, kuarsa dan batuan malihan. Dalam batupasir ditemukan fosil moluska terdiri atas Turitella terebra (Limonaceous), Olivia tricineta (Mart), Cypraea sonderava (Mart), Arca cornea (Reeva), Tapes minosa (Phil) dan Venus squamosa (Lam). Sedangkan fosil foraminifera bentonik antara lain Celanthus craticulatus, Amonia sp., Calcarina sp., Brizalina sp., Quinqueloculina sp. dan Triloculina sp. Berdasarkan kandungan fosilfosil tersebut diatas formasi ini diduga berumur Miosen Akhir-Plistosen Awal dan terendapkan di lingkungan fluvial. Tebal formasi ini diperkirakan 150 meter dan menindih tak selaras di atas formasi- formasi yang lebih tua.

Ketiga, Granit Klabat (TRJkg): terdiri atas granit biotit, granodiorit dan gneissic granit. Granit biotit berwarna kelabu, tekstur porfiritik dengan butiran kristal berukuran sedang-kasar, fenokris feldspar panjangnya mencapai $4 \mathrm{~cm}$ dan memperlihatkan struktur foliasi. Granodiorit berwarna putih kotor, berbintik hitam. Gneissic granit berwarna kelabu dan berfoliasi. Nama satuan ini berasal dari lokasi tipenya di Teluk Klabat, Bangka Utara. Pentarikhan dari 5 contoh 
granit berdasarkan metode $\mathrm{K}-\mathrm{Ar}$ dan $\mathrm{Rb}-\mathrm{Sr}$ masing-masing menunjukkan umur $201+1 \mathrm{jt}$ (Graha, 1990) dan $213+4 \mathrm{jt}, 217+15 \mathrm{jt}, 225$ $+9 \mathrm{jt}$ dan $223+16 \mathrm{jt}$ (Cobbing, 1992). Berdasarkan perian tersebut umur satuan granit ini adalah Trias Akhir-Jura Awal dan menerobos Formasi Tanjung Genting dan Kompleks Pemali.

Keempat, Formasi Tanjung Genting (TRt) terdiri atas perselingan batupasir dan batulempung. Batupasir berwarna kelabu kecoklatan, berbutir halus-sedang, sortasi baik, keras dan tebal lapisan 2-60 cm. Struktur sedimen berupa cross bedding dan ripple mark. Setempat ditemukan lensa batugamping setebal 1,5 meter. Batulempung berwarna kelabu kecoklatan, berlapis baik dengan tebal 15 meter, setempat dijumpai lensa batupasir halus. Dalam lensa batugamping Osberger menemukan fosil Montlivaultia molukkana (J. Wanner), Peronidella (G. Wilkens), Entrochus sp. dan Encrinus sp. yang menunjukkan umur Trias. Berdasarkan kandungan fosil-fosil tersebut formasi ini diduga berumur Trias Awal dan terendapkan di lingkungan laut dangkal. Kontak dengan granit ditemukan di utara Lembar Bangka Selatan. Formasi Tanjung Genting terendapkan tidak selaras di atas batuan malihan.

Kelima, Kompleks Malihan Pemali (CPp) terdiri atas phyllite, sekis dan kuarsit. Phyllite berwarna kelabu kecoklatan, foliasi dan mengandung urat kuarsa. Sekis berwarna kelabu kehijauan, foliasi, terkekarkan, setempat rekahannya terisi kuarsa atau oksida besi, berselingan dengan kuarsit. Kuarsit berwarna putih kotor sampai kecoklatan, keras, tersusun atas kuarsa dan feldspar, halus-sedang, perlapisannya mencapai $1 \mathrm{~cm}$. Umur satuan ini tidak diketahui dengan pasti, tetapi kedudukannya ditindih tidak selaras oleh Formasi Tanjung Genting, maka umurnya diduga Perm atau Karbon.

\section{Metode Magnetik}

Metode magnetik pada eksplorasi panas bumi digunakan untuk mengetahui variasi medan magnet di daerah penelitian. Variasi medan magnet disebabkan oleh sifat kemagnetan yang tidak homogen dari kerak bumi. Batuan pada sistem panas bumi umumnya memiliki magnetisasi rendah dibanding batuan sekitarnya. Hal ini disebabkan adanya proses demagnetisasi oleh proses alterasi hidrotermal, dimana proses tersebut mengubah mineral yang ada menjadi mineral-mineral paramagnetik atau diamagnetik. Nilai magnet yang rendah tersebut dapat menginterpretasikan zonazona potensial sebagai reservoir sumber panas (Fahmi, 2017).

Metode magnetik digunakan untuk mengetahui sifat-sifat magnetik batuan dibawah permukaan bumi akibat pengaruh dari batuan yang termagnetisasi. Salah satu pengukuran yang dapat dilakukan pada metode magnetik adalah untuk mengukur variasi medan magnetik di permukaan bumi (Hadisurya \& Mulyanto, 2010). Metode magnetik bekerja berdasarkan pengukuran variasi intensitas medan magnet dipermukaan bumi yang disebabkan karena perbedaan antar sifat magnetisasi batuan di kerak bumi sehingga meningkatkan munculnya medan magnet bumi yang tidak homogen atau disebut anomali magnetic (Suryanto, 2017).

\section{METODE PENELITIAN}

Pengukuran dilakukan pada panas bumi Nyelanding, Bangka Selatan dengan luas penelitian $1 \mathrm{x} \quad 1 \mathrm{~km}^{2}$. Data pada penelitian ini merupakan data yang telah diperoleh dari penilitian lapangan. Data ini memberikan informasi sifat kemagnetan (kerentanan magnet) batuan yang memperlihatkan kontras magnetik bawah permukaan daerah penilitian. Data magnetik terdiri dari data base dan data rover. Data base adalah data intensitas medan magnet terukur (nT) selama pengukuran berlangsung, 
waktu dan satu titik koordinat (UTM). Data rover adalah data intensitas medan magnet terukur setiap titik pengukuran, waktu dan titik koordinat(UTM).

\section{HASIL PENELITIAN Anomali Medan Magnet Total}

Anomali medan magnet total adalah nilai medan magnet di suatu daerah yang dihasilkan oleh batuan ataupun mineral yang berada di bawah permukaan. Anomali medan magnetic total dihasilkan dengan melakukan beberapa koreksi terhadap data hasil pengukuran di lapangan. Koreksi yang dilakukan adalah koreksi IGRF dan variasi harian.

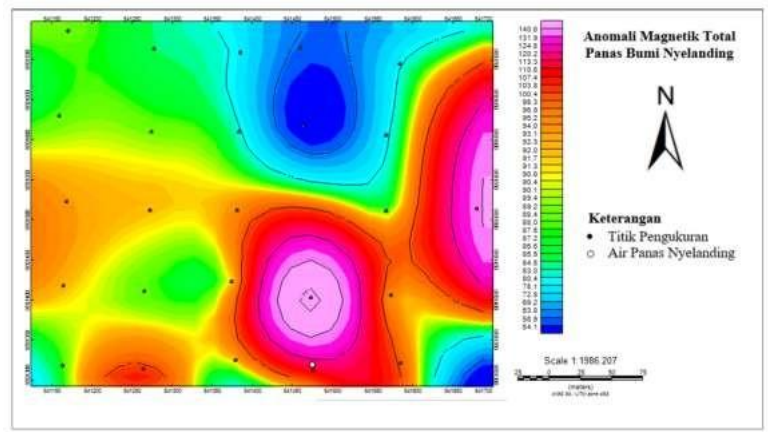

Gambar 2. Sebaran anomali magentik total

\section{Kontinuasi ke Atas}

Proses kontinuasi dengan uji trial and error dilakukan dengan melihat kecenderungan pola kontur hasil kontinuasi pada ketinggian tertentu. Penentuan ketinggian dilakukan dengan asumsi yang diperlukan dan tergantung tujuan dari efek yang ingin dihilangkankan ataupun ditampilkan. Proses ini tidak boleh menghilangkan tubuh anomali dari peta anomali yang sudah ada. Adapun target pada proses ini adalah untuk mendapatkan anomali lokal dengan menghilangkan pengaruh regional. Anomali lokal diharapkan dapat membantu dalam proses tahap interpretasi dan pemodelan struktur bawah permukaan air panas Nyelanding. Oleh karena itu, pada penelitian ini dilakukan pengangkatan ke atas setinggi 50, m, $100 \mathrm{~m}, 150 \mathrm{~m}$ dan $200 \mathrm{~m}$ dengan menggunakan perangkat lunak Oasis Montaj.

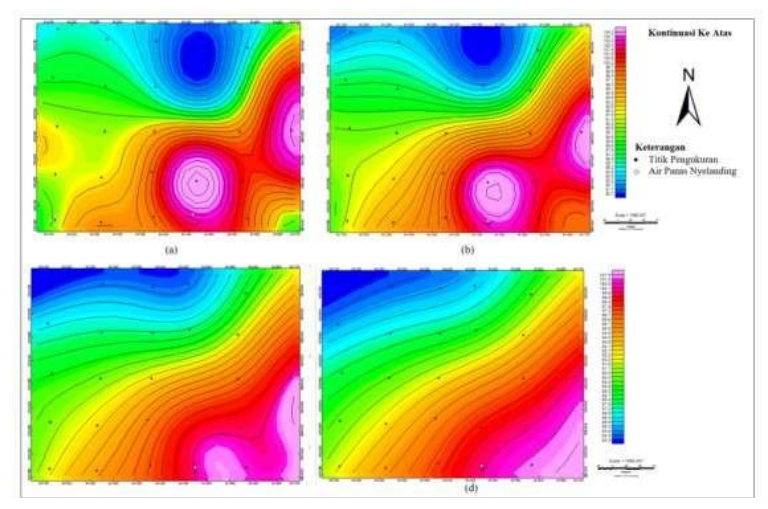

Gambar 3. Hasil kontinuasi ke atas pada ketinggian (a) 50 meter, (b) 100 meter, (c) 150 meter dan (d) 200 meter

\section{Reduksi Ke Kutub}

Hasil reduksi ke kutub menunjukkan anomaly magnet lokal menjadi satu kutub, sehingga benda penyebab anomaly medan magnet berada dibawahnya. Hasil reduksi ke kutub ditunjukkan oleh gambar 5.

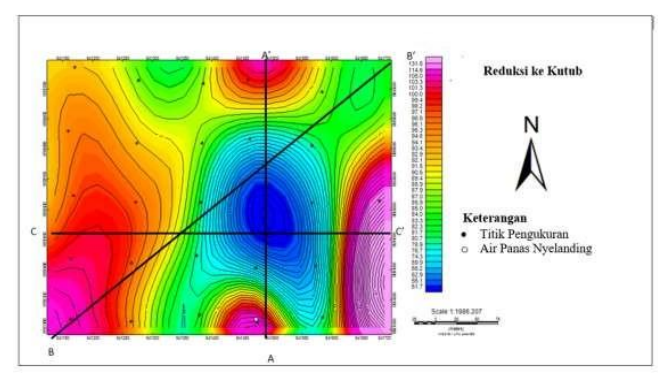

Gambar 5. Sayatan pada anomali lokal hasil reduksi ke kutub

\section{Pemodelan 2 Dimensi}

Berdasarkan hasil pemodelan sayatan A-A', ditemukan bahwa struktur bawah permukaan dikategorikan ke dalam dua struktur yaitu struktur batu granit dan struktur lapisan yang didominasi lempung, kerikil dan pasir. Batu granit yang ditandai dengan warna merah pada gambar 4.8 mempunyai nilai suseptibilitas $3 \times 10^{-3}-4 \times 10^{-}$ 
${ }^{3}$ SI yang dominan berada pada kedalaman 0 - 500 meter. Lapisan yang didominasi oleh lempung, kerikil dan pasir mempunyai suseptibilitas $1 \times 10^{-3} \mathrm{~S}$. Hasil kesesuaian medan magnet terhitung dengan medan magnet teramtai pada model sayatan A-A' memiliki nilai eror $2,3 \%$. Titik air panas berada pada titik A sayatan dengan anomali batu granit yang cukup besar. Hal ini didukung oleh keberadaan singkapan batu granit yang sangat besar pada bagian manifestasi air panas Nyelanding. Titik air panas Nyelanding berada di atas batu granit yang menerus hingga kedalaman 500 meter.

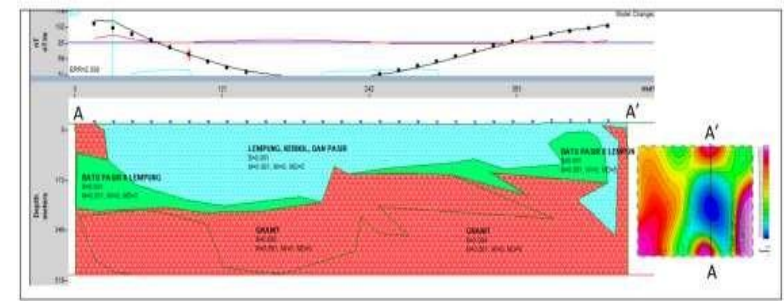

Gambar 6. Pemodelan 2 dimensi struktur bawah permukaan sayatan A-A': (a) referensi data pengukuran, (b) penampang bawah permukaan

Pada Titik B (Gambar 7), nilai medan magnet yang sangat besar (105 - 131,6 nT) dipengaruhi oleh batu granit yang berada hingga kedalaman 200 meter. Pada Titik B' (yang ditunjukkan oleh warna hijau pada timur laut daerah penelitian), nilai medan magnet sedang dipengaruhi oleh keberadaan anomali granit dari kedalaman 150 - 500 meter. Bagian tengah penelitian dengan nilai medan magnet rendah dipengaruhi oleh kondisi lapisan permukaan yang dikontrol oleh keberadaan pasir, kerikil dan lempung. Hal yang menarik pada sayatan B-B' adalah informasi bawah permukaan pada daerah timur laut daerah penelitian. Warna hijau pada peta medan magnet yang diwakili dengan warna hijau (81,7-87,9 nT) menunjukkan perselingan batu pasir lempung di atas batu granit yang menerus hingga kedalaman 500 meter. Perselingan ini merupakan hasil pelapukan intrusi batu granit menjadi batupasir - lempung akibat proses fisika dan kimiawi pada waktu yang sangat lama.

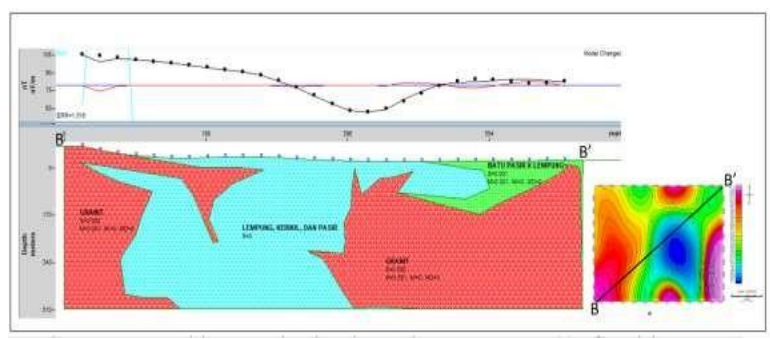

Gambar 7. Pemodelan 2D struktur bawah permukaan sayatan B-B': (a) referensi data pengukuran, (b) penampang bawah permukaan

Berdasarkan hasil reduksi ke kutub, terdapat dua anomali medan magnet tinggi ditunjukkan dengan warna merah hingga ungu pada bagian timur dan barat daerah penelitian. Pengamatan di lapangan menunjukkan bahwa daerah panas bumi nyelanding dikelilingi oleh singkapan batu granit, sehingga perlu dilakukan forward modelling dari arah barat ke timur daerah penelitian dengan memotong anomali rendah.

Hasil pemodelan C-C' menunjukkan daerah barat dan timur penelitian didominasi oleh batu granit yang dominan hingga ke dalaman 500 meter. Suseptibilitas granit pada daerah barat penelitian adalah 0,011 Si dan 0,009 untuk daerah timur penelitian. Sayatan C-C' pada gambar 4.7 juga menunjukkan bahwa kondisi bawah permukaan panas bumi Nyelanding berupa cekungan batu granit dari daerah barat hingga timur. Sayatan C-C' ini hanya terdiri dari 2 struktur yang diakibatkan oleh bongkahan batu granit yang sangat besar, sehingga anomali medan magnet yang diwakili harna hijau pada peta medan magnet tidak muncul. 


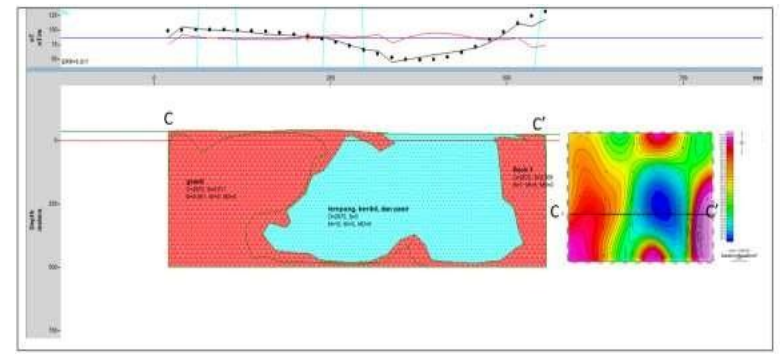

Gambar 7. Pemodelan 2 dimensi struktur bawah permukaan sayatan C-C': (a) referensi data pengukuran, (b) penampang bawah permukaan

\section{PEMBAHASAN}

\section{Anomali Medan Magnet Total}

Anomali magnetic total ditunjukkan dengan adanya perbedaan anomali suseptibilitas yang sangat besar (Susanto et al., 2017). Daerah utara penelitian menunjukkan medan magnet rendah dengan kisaran 54,1-80,4 nT yang merupakan kolam - kolam air bekas tambang timah. Adapun daerah yang dipenuhi dengan singkapan batu granit tersebar di bagian selatan daerah penelitian dan ditunjukkan oleh densitas tinggi dengan kisaran 85,4- $127,9 \quad \mathrm{Nt}$ (Gambar 2).

\section{Kontinuasi ke Atas}

Pengangkatan pada ketinggian 50 meter memperlihatkan klosur anomali tinggi dan rendah pada daerah selatan dan utara penelitian. Hasil ini menunjukkan konsistensi terhadap kemunculan anomali tinggi dan rendah pada peta anomali magnet total (Gambar 3.). Anomali tinggi pada daerah timur penelitian juga masih muncul dan sesuai dengan anomali magnet total. Proses kontinuasi pada ketinggian 50 meter masih sesuai dengan kontur anomali pada peta anomali magnet total. Kontinuasi pada ketinggian 100, 150 dan 200 meter menunjukkan hasil yang cenderung merubah informasi dari peta anomali magnet total. Pada ketinggian ini, pengaruh regional lebih mendominasi anomali magnet. Pola anomali magnet sangat berubah dan anomali lokal telah hilang.

Target pada penelitian ini adalah untuk mengetahui kondisi anomali lokal medan magnet batuan. Oleh karena itu, berdasarkan proses kontinuasi atas pada berbagai ketinggian maka pengangkatan yang digunakan pada proses selanjutnya adalah ketinggian 50 meter. Pengangkatan bertujuan untuk pemisahan anomali lokal dan regional (Susanto et al., 2017). Pengangkatan 50 meter cukup untuk menampilkan anomaly magnetic secara lokal dan tidak dipengaruhi oleh anomali regional sebagaimana ditunjukkan oleh Gambar 3. Hasil magnetik setelah dilakukan kontinuasi ke atas menunjukkan sebaran anomali magnetik lokal. Anomaly rendah diwakili warna biru dengan medan magnet sebesar 73-83,2 nT yang berada di bagian utara daerah penelitian. Anomali sedang diwakili oleh warna hijau hingga kuning dengan nilai sebesar 85,7 -91,1 nT pada daerah barat. Adapun dominasi anomaly tinggi berada di bagian utara dan selatan daerah penelitian dengan nilai sebesar 92,5-112,9 nT.

\section{Reduksi Ke Kutub}

Sifat dipol anomaly magnetik menyulitkan interpretasi data lapangan yang umumnnya masih berpola asimetris. Reduksi ke kutub bertujuan untuk melokalisasi benda -benda anomaly magnetik serta menempatkan anomaly tersebut tepat di atas sumber anomaly untuk kepentingan pemodelan penampang bawah permukaan dan interpretasi (Indratmoko, 2009). Prosesi ini dilakukan dengan menggunakan software Oasis Monjat.

\section{Pemodelan 2 Dimensi}

Berdasarkan hasil pemodelan 2 dimensi, maka didapatkan bahwa kondisi struktur bawah permukaan panas bumi Nyelanding dikontrol oleh keberadaan batu granit dengan suseptibilitas 0,009-0,05 SI dan lapisan lempung, kerikil dan lanau dengan suseptibilitas $0,00001 \quad-\quad 0,00005$ SI. 
Suseptibilitas ini sangat penting dalam pencarian benda anomali karena sifatnya yang sangat khas untuk setiap jenis mineral atau logam (Jahidin et al., 2011). Batu granit di bawah permukaan diperkirakan merupakan batuan yang mengantarkan dan mengakumulasi panas pada manifestasi panas bumi Nyelanding. Dalam penelitian ini tidak didapatkan adanya produk - produk gunung api seperti fumarol dan sulfatara. Namun, keberadaan batu granit sebagai anomali yang cukup konsisten di daerah penelitian menunjukkan bahwa keberadaan air panas Nyelanding mempunyai hubungan yang erat dengan batu granit. Oleh karena itu, hasil penelitian ini dapat dijadikan sebagai landasan dalam mempelajari komposisi batu granit dan relasinya dengan produksi panas bumi Nyelanding.

\section{SIMPULAN}

Terdapat dua perlapisan batuan di bawah air panas Nyelanding yaitu batu granit dengan suseptibilitas 0,009-0,05 SI dan lapisan lempung, kerikil dan lanau dengan suseptibilitas 0,00001 - 0,00005 SI. Geologi lokal daerah air panas Nyelanding didominasi oleh keberadaan batu granit hingga kedalaman 500 meter. Hasil forward modelling pada lapisan A-A' dan C-C' menunjukkan struktur bawah permukaan air panas Nyelanding berupa cekungan batu granit yang diperkirakan dapat mengakumulasi panas bumi.

\section{DAFTAR PUSTAKA}

Afandi, A., Maryanto, S., \& Rachmansyah, A. (2013). Identifikasi Reservoar Daerah Panasbumi dengan Metode Geomagnetik Daerah Blawan Kecamatan Sempol Kabupaten Bondowoso. J. Neutrino, 6(1), 1-10. https://doi.org/10.18860/neu.v0i0.244 1

Chappell, B.W., \& White, A. J. R. (2001) Two Contrasting Granite Types: 25 Years later. Australian Journal of
Earth Sciences, 48(4), 489-499. http://dx.doi.org/10.1046/j.14400952.2001.00882.x

Cobbing, E. J., Pitfield, P. E. J., Darbyshire, D. P. F., \& Malick, D. I. J. (1992). The Granites of the South-East Asian Tin Belt. London: HMSO

Fahmi, L. C. (2017). Pemetaan Struktur Bawah Permukaan di Sekitar Manifestasi Panas Bumi Krakal dengan menggunakan Metode Geomagnetic. Skripsi. Universitas Negeri Semarang. Semarang

Franto, F. (2015). Citra Shuttle Radar Topography Mission (SRTM) (Interpretation Structure of Regional Geology on Bangka Island with Shuttle Radar Topography Mission (SRTM)). J. Promine, 3(1), 10-20. https://doi.org/10.33019/promine.v3i1 .85

Hadisurya, D., \& Mulyatno, B. S. (2010). Identifikasi Magma Chamber berdasarkan Analisis Data Magnetik Total di Gunung Ili Lewotolo Kabupaten Lembata, Nusa Tenggara Timur berdasarkan Data Survei Tahun 2010. Skripsi. Universitas Lampung. Lampung

Indratmoko, P., Nurwidyanto, M. I., \& Yulianto, T. (2009). Interpretasi Bawah Permukaan Daerah Manifestasi Panas Bumi Parang Tritis Kabupaten Bantul DIY dengan Metode Magnetik. Berkala Fisika, 12(4), $153 \quad-\quad 160$. https://ejournal.undip.ac.id/index.php/ berkala_fisika/article/view/2924

Jahidin, J., Ngkoimani, L. O., \& Bijaksana, S. (2011). Analisis Suseptibilitas Magnetik Batuan Ultrabasa di Desa Mosolo Pulai Wawonii Provinsi Sulawesi Tenggara. Bandung: ITB

Kasbani, K. (2009). Tipe Sistem Panas Bumi di Indonesia dan Estimasi Potensi Energinya. Bul. Sumber Daya Geol, 4(3),

23-30. 
https://doi.org/10.47599/bsdg.v4i3.18

4

Pitulima, J., \& Siregar, R. N. (2016). Identifikasi Struktur Geologi Sumber Air Panas Non Volkanik desa Nyelanding Bangka Selatan dengan menggunakan Metode Geolistrik Konfigurasi Wenner. Prosiding SNRT (Seminar Nasional Riset Terapan). Banjarmasin.

Putri, D. A. B., \& Harianja, A. K. (2021). Identifikasi Prospek Panas Bumi Radiogenik Menggunakan Landsat-8 dan Gravitasi di Daerah Permis. Jurnal Geofisika Eksplorasi, 07(01), 52-70.

https://doi.org/10.23960/jge.v7i1.115

Susanto, R. A., Sehah, S., \& Irayani, Z. (2017). Interpretasi Data Anomali Medan Magnetik untuk Mengidentifikasi Peninggalan Kadipaten Pasir Luhur Desa Tamansari Karanglewas. JPF, 5(1), 34-45.

https://media.neliti.com/media/publica tions/138668-ID-interpretasi-dataanomali-medan-magnetik.pdf 